\title{
METODE PENGEMBANGAN SOCIAL QUESTION PADA ANAK DALAM PERSPEKTIF PEMBIMBING
}

\author{
SARONO WIJIO \\ STIT Iqra' Kapuas Hulu \\ Aron_Syahroni@yahoo.co.id
}

\begin{abstract}
Social intelligence is currently seen as a determining factor for a child's success in education. The purpose of this study is to describe the social intelligence of children and methods for developing children's social intelligence. This type of research is qualitative descriptive which is directly carried out on the object under study in order to produce the necessary data and to answer the problem formulation, namely: how is the supervisor's understanding of social intelligence in children and the guidance method in directing children to develop social intelligence in Kindergarten Pembina I Putussibau. Data collection was carried out by interviewing, observing and documenting the research data sources which included: supervising teachers at Kindergarten Pembina I Putussibau, students, brochures and curriculum. The qualitative descriptive method was used as data analysis by means of the available data being processed during the next research to be systematically interpreted into reports. It is known that the research results are as follows: 1) The supervisor's understanding of social intelligence in children is that social intelligence is the ability shown by children when interacting with other people or the social environment. 2) The method used by the supervisor in practically developing children's social intelligence is with individual and group guidance, while theoretically the approach used by the supervisor is the cognitive and social learning approach from Albert Bandura.
\end{abstract}

\footnotetext{
ABSTRAK

Social intelligence is currently seen as a determining factor for a child's success in education. The purpose of this study is to describe the social intelligence of children and methods for developing children's social intelligence. This type of research is qualitative descriptive which is directly carried out on the object under study in order to produce the necessary data and to answer the problem formulation, namely: how is the supervisor's understanding of social intelligence in children and the guidance method in directing children to develop social intelligence in Kindergarten Pembina I Putussibau. Data collection was carried out by interviewing, observing, and documenting the research data sources which included: supervising teachers at Kindergarten Pembina I Putussibau, students, brochures, and curriculum. The qualitative descriptive method was used as data analysis by means of the available data being processed during the next research to be systematically interpreted into reports. It is known that the research results are as follows: 1) The supervisor's understanding of social intelligence in children is that social intelligence is the ability shown by children when interacting with other people or the social environment. 2) The method used by the supervisor in practically developing children's social intelligence is with individual and group guidance, while theoretically, the approach used by the supervisor is the cognitive and social learning approach from Albert Bandura.
}

Kata Kunci: bimbingan kecerdasan sosial, anak TK 
Wijio, $S$.

Metode Pengembangan Social Question Pada Anak Dalam Perspektif Pembimbing

Cara mengutip: Wijio, S. (2020). Metode Pengembangan Social Question Pada Anak Dalam Perspektif Pembimbing. Nusantara of Research : Jurnal Hasil-Hasil Penelitian Universitas Nusantara PGRI Kediri (eJournal), 7(1), 37-48. https://doi.org/10.29407/nor.v7i1.15055

\section{PENDAHULUAN}

Manusia merupakan makhluk sosial yang membutuhkan interaksi antar sesamanya. Sejak anak dilahirkan ia sudah memiliki naluri berinteraksi dengan oran lain. Seiring bertambahnya usia kebutuhan sosial anak ikut semakin kompleks. Mereka sudah butuh teman sebaya, perlu memahami orang dewasa selain orang tua misalnya guru (Wiwik, 2008:49). Ketika memasuki pra sekolah, anak akan mulai menjelajahi lingkungan sosial teman sebaya dan orang dewasa selain orang tua. Disinilah kecerdasan sosial anak mulai berkembang melalui interaksi sosial yang dilakukannya.

Dari interaksi sosial mereka dapat memenuhi kebutuhan akan perhatian, kasih sayang dan cinta. Untuk itulah teman dan lingkungan yang mendukung menjadi penentu kematangan psikologis anak kelak. Anak yang terisolasi akan menjadi pribadi yang tidak matang secara sosial, emosional dan spiritual. Mereka akan memiliki kepribadian yang terganggu akibat kehilangan kasih sayang dan cinta dari lingkungan sosialnya sehingga mereka akan menjadi pribadi anti sosial. Akibatnya mereka tidak bisa mengembangkan hubungan yang harmonis dengan orang lain (Safari, 2005:39).

Anak yang terisolasi secara sosial menunjukkan gejala-gejala yang tidak sehat. Gejala ini merupakan suatu penyakit sosial yang disebut malu. Akibat jangka panjang dari rasa malu yang berlebih-lebihan ini memunculkan penyakit sosial seperti kesepian, rendah diri, menarik diri, penilaian sosial yang kurang baik, bahkan dikatakan sebagai orang yang tidak ramah (Safari, 2005:13).

Dalam penelitiannya Safari (2005: 40) menjelaskan bahwa anak-anak yang dikucilkan mempunyai karakteristik negatif seperti agresif, suka menyerang, bertindak anti sosial, sukar bekerja sama,sukar bekerjasama, ingin menang sendiri, dan selalu mengganggu kesenangan temannya.

Pada aspek dikucilkan menyebabkan anak sering terlihat murung, sedih, bahkan menangis karena merasa selalu dijauhi oleh teman-temannya (Ria dkk., 2013: 89). Berbeda dengan anak-anak yang disukai, cenderung memiliki karakteristik positif seperti suka menolong, baik hati, perhatian, pengertian dengan perasaan orang lain, dan lebih cakap dalam interaksi sosialnya (Safari, 2005:40).

Anak-anak yang gagal dalam mengembangkan kecerdasan sosial akan banyak mengalami hambatan dalam dunia sosialnya. Seperti yang dikemukakan oleh Victor Frankl sebagai simptom noogenis neurosis atau eksistensial vacumm. Anak-anak yang terbatas pergaulan sosialnya ini jelas akan banyak mengalami hambatan ketika mereka memasuki masa sekolah atau masa dewasa (Safari, 2005: 13-14).

Sejak usia dini kecerdasan sosial penting untuk dikembangkan sebab, semakin maju perkembangan dunia maka dibutuhkan orang-orang yang memiliki kecerdasan sosial dalam dunia kerja serta kehidupan sosialnya. Mengingat anak adalah sebagai generasi penerus dan 
Wijio, S.

Metode Pengembangan Social Question Pada Anak Dalam Perspektif Pembimbing

pemimpin masa depan, maka anak layak mendapatkan pendidikan dan bimbingan untuk mengembangkan kecerdasan sosialnya sejak dini, sebagai suatu upaya preventif atas hambatan-hambatan dalam dunia sosialnya pada masa yang akan datang.

Taman Kanak-kanak merupakan salah satu bentuk pendidikan pra sekolah yang memiliki tujuan membantu anak didik mengembangkan potensi baik psikis dan fisik yang meliputi moral dan nilai-nilai agama, sosial, emosional, kognitif, bahasa fisik atau motorik, kemandirian dan seni untuk siap memasuki pendidikan dasar (Mansur, 2009: 110). Salah satu keuntungan pendidikan pra sekolah adalah bahwa pusat pendidikan tersebut memberikan pengalaman sosial di bawah bimbingan para guru yang terlatih yang membantu mengembangkan hubungan yang menyenangkan dan berusaha agar anak-anak tidak mendapat perlakuan yang mungkin menyebabkan mereka menghindari hubungan sosial (Elizabeth, 1992: 261). Anak yang mengikuti pendidikan pra sekolah melakukan penyesuaian sosial yang lebih baik dibandingkan dengan anak-anak yang tidak mengikuti pendidikan pra sekolah (Elizabeth, 1992: 261). Alasannya adalah mereka dipersiapkan secara lebih baik untuk melakukan partisipasi yang aktif dalam kelompok dibandingkan dengan anak-anak yang aktivitas sosialnya terbatas dengan anggota keluarga dan anak-anak dari lingkungan tetangga terdekat.

Keberadaan taman kanak-kanak sebagai tempat pendidikan anak merupakan potensi awal bagi terwujudnya perkembangan sosial anak. Melalui TK tersebut anak mulai diajarkan untuk saling mengenal dan berinteraksi sesama teman. Dengan demikian, stimulasi perkembangan anak akan terfasilitasi lebih baik dibandingkan dengan anak yang tidak masuk TK. Anak akan dapat pengalaman dan dan perlakuan yang akan meningkatkan perkembangan fisik, emosi, sosial dan intelektualnya secara lebih baik (Elizabeth, 1992: 76). Berdasarkan hal tersebut menarik bagi peneliti untuk meneliti tentang konsep dan metode yang dimiliki pembimbing dalam mengarahkan anak untuk mengembangkan kecerdasan sosial di TK Pembina I Putussibau.

\section{METODE}

Model penelitian ini adalah kualitatif dengan menghasilkan data deskriptif dari pembimbing yang diteliti dan pengamatan perilaku siswa. Subyek penelitian adalah sumber data dimana peneliti dapat memperoleh data yang diperlukan dalam rangka penelitian (Arikunto, 2002: 102). Adapun subyek penelitian dalam penelitian ini adalah Kepala Sekolah TK Pembina I Putussibau dan Pembimbing (guru sekaligus wali kelas). Obyek penelitian ini adalah pemahaman para pembimbing terkait kecerdasan sosial dan metode dari pembimbing untuk mengarahkan anak TK dalam mengembangkan kecerdasan sosial.

Metode pengumpulan data dalam penelitian ini menggunakan observasi, wawancara dan dokumentasi. Data yang digali melalui observasi yaitu kegiatan bimbingan kecerdasan sosial dan perilaku sosial anak TK. Sedangkan wawancara digunakan untuk menggali data berupa gambaran dari para pembimbing terkait kecerdasan sosial dan cara pembimbing dalam mengarahkan anak untuk mengembangkan kecerdasan sosial yang meliputi: social insight berupa kesadaran diri, pemahaman situasi sosial dan etika sosial, dan keterampilan 
pemecahan masalah; social sensitivity berupa sikap empati dan sikap prososial; social communication berupa komunikasi efektif dan mendengarkan efektif. Untuk mengumpulkan berbagai sumber dokumen, berbagai catatan yang mengandung petunjuk tertentu menggunakan metode observasi. Sebagai alat pembuktian dan bahan untuk mendukung keterangan maka digunakan dokumen-dokumen tersebut.

\section{HASIL}

\section{Pemahaman Pembimbing tentang Kecerdasan Sosial}

Untuk mengetahui lebih jelas sejauh mana pemahaman pembimbing kaitannya dengan kecerdasan sosial dengan melihat aspek pertumbuhan dan perkembangan anak akan tersaji dalam pembahasan berikut ini melalui wawancara langsung dengan pembimbing TK Pembina I Putussibau yaitu Ibu Muharromah (2016): "Kalau menurut saya kecerdasan sosial itu bisa komunikasi sama orang lain, terus bisa berinteraksi sama orang lain, terus misalkan dengan kondisi baru..seperti awal-awal gini dia bisa langsung ditinggal sama orang tuanya, jadi langsung bisa menyesuaikan dengan kondisi yang baru".

Dari ungkapan informan di atas dapat diperoleh keterangan bahwa kecerdasan sosial anak itu bisa diketahui melalui kemampuan berkomunikasi anak dengan lain orang, berinteraksi dengan orang lain serta dapat menyesuaikan diri pada kondisi yang baru dimana anak ketika itu berada, khususnya lingkungan sekolah. Dari pendapat yang dikemukakan oleh pembimbing di atas, secara garis besar dapat disimpulkan bahwa kecerdasan sosial adalah kemampuan anak untuk berkomunikasi dan menyesuaikan diri saat berinteraksi dengan lingkungan sosial ia berada.

\section{Metode Pembimbing dalam Mengarahkan anak TK untuk Mengembangkan Kecerdasan Sosial}

Kecerdasan sosial merupakan kecerdasan yang lebih bersifat cristallized. Intelegensi cristallized dapat dipandang sebagai endapan pengalaman yang terjadi sewaktu intellegensi fluid bercampur dengan apa yang disebut intelligensi budaya. Intelligensi cristallized akan meningkat kadarnya dalam diri seseorang seiring dengan bertambahnya pengetahuan, pengalaman dan keterampilan-keterampilan yang dimiliki individu (Safaria, 2005: 24). Maka jelas bahwa kecerdasan sosial ini bersifat berubah dan dapat ditingkatkan. Dikarenakan sebuah proses belajar dari pengalaman anak sehari-hari, bukan merupakan faktor hereditas. Semua anak dapat memiliki kecerdasan sosial yang tinggi, untuk itu anak membutuhkan bimbingan dan pengarahan baik orang tua ketika di rumah maupun pembimbing (guru) ketika di sekolah untuk mengembangkan kecerdasan sosialnya. Sesuai pertumbuhan dan perkembangannya anak pada umur 4 sampai 6 tahun, maka untuk mengarahkan anak TK untuk dapat mengembangkan kecerdasan sosial, pembimbing menggunakan metode berikut:

\section{Mengembangkan kesadaran diri anak}

Kesadaran diri merupakan kecenderungan individu untuk dapat menyadari dan memperhatikan aspek diri internal maupun aspek diri eksternalnya. Dalam pelaksanaannya, pembimbing menggunakan cara-cara sebagai berikut: dialog, berkaitan dengan cara 
Wijio, $S$.

Metode Pengembangan Social Question Pada Anak Dalam Perspektif Pembimbing

pembimbing dalam mengarahkan anak menyadari pikiran, emosi-emosi dan perasaan anak, maka pembimbing mengarahkan anak menyadari keadaan internalnya maka pembimbing mengajak anak untuk berdialog atau bicara penuh empati. Diperlukan pendekatan interpersonal antara pembimbing dan anak, dimana pendekatan itu dapat dikembangkan dengan mengajukan pertanyaan-pertanyaan yang empatik atas apa yang dirasakan anak. Dialog juga digunakan pembimbing untuk mengarahkan anak menyadari tindakan-tindakan atau pengalamannya yang kurang baik; memberikan reward (penghargaan), Cara yang digunakan pembimbing dalam mengarahkan anak menyadari tindakan-tindakan atau pengalaman bagus yang sudah dia lakukan, adalah dengan cara memberikan reward (penghargaan). Reward (penghargaan) merupakan salah satu cara yang efektif untuk diterapkan pada usia kanakkanak. Selain sebagai penyemangat juga sebagai bentuk penegasan atas sebuah tindakan yang dinilai bagus; Pembiasaan, merupakan cara yang diterapkan pembimbing untuk mengembangkan kesadaran diri anak dalam aspek eksternal, yaitu penampilan, pola interaksi dengan lingkungan sosial dan menyadari situasi di sekelilingnya.

Menurut pendapat Ahmad Tafsir (2004: 144) inti pembiasaan adalah pengulangan terhadap segala sesuatu yang dilaksanakan atau diucapkan seseorang. Cara ini sangat tepat diterapkan pada usia pra sekolah karena anak-anak usia pra sekolah memiliki daya tangkap dan potensi dalam menerima pengajaran dan pembiasaan adalah sangat besar dibandingkan usia lainnya. Akan menjadi lebih optimal apabila pembiasaan-pembiasaan baik yang diajarkan di sekolah turut di biasakan juga di lingkungan rumah oleh orang tua.

\section{Mengajarkan pemahaman situasi sosial dan etika sosial pada anak}

Dari informasi yang diperoleh dari pembimbing, menerangkan bahwa dalam mengajarkan pemahaman situasi sosial dan etika sosial pada anak TK, pembimbing terlebih dahulu menjadi contoh/teladan bagi anak-anak, baik dalam berperilaku maupun bertutur kata. Sehingga anak-anak akan belajar dengan menconton apa yang dilakukan gurunya, guru disini berperan sebagai model bagi anak-anak. Dalam pelaksanaanya guru menjadi model untuk semua anak didik, sehingga metode yang diterapkan pembimbing disini bisa dikategorikan dalam bimbingan kelompok.

\section{Mengajarkan pemecahan masalah efektif pada anak}

Pelaksanaan bimbingan untuk mengajarkan pemecahan masalah efektif pada anak termasuk dalam kategori bimbingan individu yang menggunakan pendekatan kognitif, yakni pembimbing mengarahkan anak untuk menyadari apa yang ada dipikirannya dan mengevaluasi dirinya sendiri. Pembimbing juga memberikan kesempatan kepada anak untuk berargumentasi, sehingga selama proses komunikasi ersebut pola pikir anak yang salah bisa dirubah secara perlahan. Strategi yang diterapkan pembimbing dalam mengajarkan pemecahan masalah efektif pada anak TK sesuai dengan Strategi pemecahan konflik "kolaborasi" yang dikemukakan oleh Isenhart dan Spangle, dimana strategi ini melibatkan kerjasama antara kedua belah pihak untuk sama-sama mendiskusikan permasalahannya dan mencari pemecahan yang menguntungkan kedua belah pihak. Strategi kolaborasi dalam memecahkan suatu konflik menekankan tercapainya solusi menang-menang (win-win solution) (Safaria, 2005: 78). 


\section{Mengembangkan sikap empati anak}

Dalam mengembangkan sikap empati anak TK, pembimbing lebih banyak menggunakan cara cerita/dongeng, baik dengan media gambar, media peraga, atau tanpa media sekalipun. Dalam perspektif pendidikan Islam, bercerita merupakan metode komunikasi universal yang sangat berpengaruh pada jiwa manusia.

\section{Mengembangkan sikap prososial anak}

Dalam mengembangkan sikap prososial anak dengan cara memberikan contoh/teladan, maka guru tidak hanya bicara tapi juga melakukan. Anak akan meniru apa yang dilakukan gurunya. Cara belajar dengan mencontoh ini juga sesuai dengan teori belajar sosial dengan mencontoh (observational learning) yang dikemukakan oleh Bandura (1977).

\section{Mengajarkan komunikasi dengan santun pada anak}

Dalam kehidupan sehari-hari anak tidak lepas dari pengaruh lingkungan sosial. Selain lingkungan sekolah anak juga mendapat pengaruh dari lingkungan rumah dan teman bermain, kadangkala tak selamanya pengaruh lingkungan sosial itu baik. Ada kalanya anak mendapat pengaruh buruk dari lingkungan sosial di luar sekolah, misalnya anak berkata yang kurang sopan. Maka menjadi kewajiban guru di sekolah untuk selalu mengingatkan anak untuk berkata yang baik dan sopan.

\section{Mengajarkan mendengar efektif pada anak}

Pengkondisian dilakukan pembimbing untuk memusatkan perhatian anak-anak yang sudah terpecahkan saat proses belajar mengajar di kelas. Metode ini merujuk pada teori classical conditioning yang dikemukakan oleh Pavlov, bahwa perilaku manusia merupakan fungsi dari stimulus. Individu dapat dikendalikan melalui cara mengganti stimulus alami dengan stimulus yang tepat untuk mendapatkan pengulangan respon yang diinginkan, sementara individu tidak menyadari bahwa ia dikendalikan oleh stimulus yang berasal dari luar.

Ketika pembimbing memberikan stimulus dengan mengatakan "tepuk satu", maka respon yang ditunjukkan adalah secara spontan anak akan menjawab "one yes" dan langsung diam. Pembimbing tidak perlu berteriak-teriak untuk menyuruh anak diam, pembimbing menggantinya dengan satu kata sebagai stimulus yang tepat untuk membuat anak diam, tanpa anak menyadari kalau sebenarnya mereka disuruh diam

\section{PEMBAHASAN}

\section{Pengertian Perkembangan Sosial Anak}

Menurut Elizabeth B Hurlock (2005: 250) Perkembangan sosial berarti perolehan kemampuan berperilaku yang sesuai dengan tuntutan sosial. Sedangkan menurut Syamsu Yusuf (2005: 124), perkembangan sosial merupakan pencapaian kematangan sosial. Anak harus belajar tentang cara menyesuaikan diri dengan orang lain. Kemampuan ini diperoleh anak melalui berbagai kesempatan atau pengalaman bergaul dengan lingkungan, baik di keluarga, teman bermainnya, dan orang dewasa. 
Wijio, S.

Metode Pengembangan Social Question Pada Anak Dalam Perspektif Pembimbing

Menurut Soemiarti Patmonodewo (2003: 31) perkembangan sosial biasanya dimaksudkan sebagai perkembangan tingkah laku anak dalam menyesuaikan diri dengan aturan-aturan yang berlaku di dalam masyarakat di mana anak berada. Kemampuan sosialisasi anak adalah hasil belajar bukan sekedar hasil dari kematangan saja. Perkembangan sosial diperoleh dari kematangan dan kesempatan belajar dari berbagai respons lingkungan terhadap anak.

\section{Pola perkembangan sosial pada anak}

\section{Masa bayi}

Masa ini dimulai atau berlangsung dari umur 2 minggu sampai 2 tahun. Kontak sosial bayi dengan pengasuhnya diperkirakan mulai terjadi pada usia 2 bulan, yaitu pada saat bayi mulai tersenyum ketika memandang wajah ibunya. Perkembangan awal kontak sosial pada bayi ini merupakan dasar bagi pembentukan hubungan sosial di kemudian hari (Desmita, 2006: 119). Karena kehidupan bayi berpusat di sekitar rumah, maka di rumahlah diletakkan dasar perilaku dan sikap sosialnya kelak.

\section{Masa kanak-kanak awal}

Masa kanak-kanak awal dimulai saat masa bayi berakhir, yaitu pada usia 2 tahun. Pola perilaku sosial atau perilaku yang tidak sosial dibina pada masa kanak-kanak awal atau masa pembentukan, pengalaman sosial awal sangat menentukan kepribadian setelah anak menjadi orang dewasa (Elizabeth, 2005: 256). Pengalaman sosial awal dapat berupa hubungan antar anggota keluarga atau orang-orang diluar lingkungan keluarga. Dari hasil studi terhadap anak-anak dalam periode tertentu, Waldrop dan Halyerson telah menyimpulkan bahwa " sosiabilitas pada umur $2 \frac{1}{2}$ tahun dapat meramalkan sosiabilitas pada umur $7 \frac{1}{2}$ tahun". Karena pola sikap dan perilaku cenderung menetap, tampak jelas adanya keharusan meletakkan dasar yang baik pada usia dini (Elizabeth, 2005: 258).

Menurut Reni Akbar- Hawadi (2001:17), kebanyakan pola perilaku pada anak telah terbentuk saat anak mulai masuk Taman Kanak-kanak. Dimana usia masuk Taman Kanakkanak adalah 4 sampai 6 tahun. Sehingga untuk anak usia 4 sampai 6 tahun lebih menekankan pada pengembangan dari pola perilaku sosial yang sudah dibentuk oleh orang tua/anggota keluarga di rumah.

Usia TK atau 4-6 tahun, merupakan fase penting dalam mengembangkan dasar hubungan sosial dan pola perilaku sosial yang sudah dibentuk/dibina oleh orang tua di lingkungan rumah. Karena pada masa ini anak mulai mengembangkan interaksi sosialnya dengan lingkungan baru di luar keluarga. Jika hubungan sosial dan pola perilaku sosial pada masa ini mampu berkembang dengan baik, maka anak tidak akan mengalami banyak hambatan dalam mengembangkan hubungan sosial yang lebih luas dikemudian hari. 
Wijio, S.

Metode Pengembangan Social Question Pada Anak Dalam Perspektif Pembimbing

\section{Tinjauan Tentang Bimbingan Kecerdasan Sosial}

\section{Pengertian Bimbingan Kecerdasan Sosial}

Stoops dalam Djumhur (1975: 25) mengemukakan bimbingan adalah "suatu proses yang terus menerus dalam membantu perkembangan individu untuk mencapai kemampuannya secara maksimal dalam menggerakkan manfaat yang sebesar-besarnya baik bagi dirinya maupun masyarakat". Dalam buku Dasar- Dasar Konseptual Bimbingan dan Konseling Islami, Thohari (1992: 3) menjelaskan bahwa bimbingan memiliki sifat dan fungsi preventif yakni memusatkan diri pada pencegahan munculnya masalah, sedangkan untuk kuratif (penyembuhan) merupakan sifat dan fungsi dari konseling. Thorndike (1920), memberikan argumentasi kecerdasan sosial adalah kemampuan seseorang untuk memahami, mengelola dan beradaptasi saat berinteraksi dengan orang lain. Selain itu kecerdasan sosial juga didefinisikan sebagai simpanan pengetahuan tentang dunia sosial, jalinan hubungan, dan kemampuan menghadapi orang-orang yang memiliki latar belakang yang berbeda.

Menurut Moss (2008), kemampuan menjalin hubungan dengan orang lain secara kontinyu adalah kecerdasan sosial. Dari berbagai pengertian di atas ditarik kesimpulan bahwa bimbingan kecerdasan sosial merupakan usaha yang dilakukan guna mengarahkan seseorang untuk dapat mengembangkan kemampuan memahami, mengelola, dan beradaptasi saat berinteraksi dengan orang lain.

\section{Dimensi Kecerdasan Sosial}

Kecerdasan sosial mempunyai tiga dimensi utama yaitu: Sensitivitas sosial (social sensitivity) adalah kemampuan anak untuk mampu merasakan dan mengamati reaksi-reaksi atau perubahan orang lain yang ditunjukkanya baik secara verbal maupun non verbal. Anak yang memiliki sensitivitas sosial yang tinggi akan mudah memahami dan menyadari adanya reaksi-reaksi tertentu dari orang lain, entah reaksi tersebut positif atau negatif; Social Insight, yaitu kemampuan anak untuk memahami dan mencari pemecahan masalah yang efektif dalam suatu interaksi sosial, sehingga masalah-masalah tersebut tidak menghambat apalagi menghancurkan relasi sosial yang telah dibangun anak. Tentu saja pemecahan masalah yang ditawarkan adalah pendekatan menang-menang atau win-win solution. Di dalamnya juga terdapat kemampuan anak dalam memahami situasi sosial dan etika sosial sehingga anak mampu menyesuaikan dirinya dengan situasi tersebut. Fondasi dasar dari social insight ini adalah berkembangnya kesadaran diri anak secara baik. Kesadaran diri yang berkembang ini akan membuat anak mampu memahami keadaan dirinya baik keadaan internal maupun eksternal seperti menyadari emosi-emosinya yang sedang muncul (internal) atau menyadari penampilan cara berpakaiannya sendiri, cara berbicaranya dan intonasi suaranya (eksternal); Penguasaan keterampilan komunikasi sosial (Social Communication), merupakan kemampuan individu untuk menggunakan proses komunikasi dalam menjalin dan membangun hubungan sosial yang sehat. Dalam proses menciptakan, membangun dan mempertahankan relasi sosial, maka seseorang membutuhkan sarananya. Tentu saja sarana yang digunakan adalah melalui proses komunikasi, yang mencakup komunikasi verbal, non-verbal maupun komunikasi melalui penampilan fisik. Keterampilan kominikasi yang harus dikuasai adalah keterampilan 
Wijio, $S$.

Metode Pengembangan Social Question Pada Anak Dalam Perspektif Pembimbing

mendengarkan efektif, keterampilan berbicara efektif, keterampilan public speaking dan keterampilan menulis secara efektif.

\section{Tinjauan Tentang Bimbingan Kecerdasan Sosial pada anak TK}

\section{Pengertian Bimbingan Kecerdasan Sosial pada anak TK}

Bimbingan Kecerdasan Sosial pada anak TK yang dimaksud dalam penelitian ini adalah usaha yang dilakukan untuk mengarahkan anak usia 4-6 tahun yang masuk pendidikan TK untuk dapat mengembangkan kemampuan memahami, mengelola, dan beradaptasi saat berinteraksi dengan orang lain. Untuk melaksanakan perlu suatu metode yang merupakan cara yang dilewati untuk menggapai tujuan tertentu. Metode ini dipilih dan diterapkan sesuai tingkat perkembangan dan karakteristik anak. Sehingga metode yang dipakai sangat beragam.

\section{Metode Bimbingan Kecerdasan Sosial}

Unsur penting penyelenggaraan bimbingan kecerdasan sosial pada anak adalah metode. Agar kegiatan berjalan dengan baik, metode yang dimiliki harus sesuai dengan keadaan klien bimbingan. Menurut T. Safaria (2005) ada tujuh metode bimbingan untuk mengembangkan kecerdasan sosial anak, antara lain sbb: a) Mengembangkan kesadaran diri anak; Kesadaran diri merupakan kecenderungan individu untuk dapat menyadari dan memperhatikan aspek diri internal maupun aspek diri eksternalnya. Artinya anak memiliki dua aspek dalam kesadaran akan dirinya yaitu aspek diri internal (privat) yang berkaitan dengan kemampuan anak menyadari keadaan internalnya seperti pikirannya, perasaannya, emosiemosinya, pengalamannya dan tindakan-tindakan yang diambilnya. Sedangkan aspek diri eksternal (publik) adalah kemampuan anak untuk menyadari penampilannya, pola interaksinya dengan lingkungan sosial, dan menyadari situasi yang terjadi di sekelilingnya. Kesadaran diri anak bisa dikembangkan dengan melatih dan mendorong anak untuk: Berada pada konteks di sini dan kini (here and now), Mempertajam, memperdalam dan memperluas kesadarannya (awareness) pada pengalaman yang sedang terjadi secara terus-menerus (ongoing experience), Memusatkan dan memfokuskan kesadarannya pada hal-hal yang sengaja dihindari, dilupakan, diabaikan, diacuhkan atau diminimalisir anak dari kesadarannya.Ketiga langkah tersebut bisa dilakukan dengan cara mengajukan pertanyaan atau melalui instruksi;

Mengajarkan pemahaman situasi sosial dan etika sosial pada anak, untuk sukses dalam membina dan mempertahankan sebuah hubungan, anak perlu memahami norma-norma sosial yang berlaku. Di dalamnya terdapat ajaran yang membimbing anak bertingkah laku yang benar dalam situasi sosial. Setiap situasi sosial menuntut aturan sendiri, inilah yang dinamakan sebagai etiket atau kaidah sosial yang mengatur perilaku mana yang harus dilakukan dan perilaku mana yang dilarang untuk dilakukan. Aturan ini mencakup banyak hal seperti bagaimana etiket dalam bertamu, berteman, makan, minum, bermain, meminjam, meminta tolong, dsb. Semua itu akan dihadapi anak dalam kehidupan sehari-hari, sehingga perlu diajarkan kepada anak. Muaranya anak akan mengerti bagaimana harus menyesuaikan perilakunya dalam setiap situasi sosial. 
Mengajarkan pemecahan masalah efektif pada anak, secara garis besar ada dua macam strategi di dalam memecahkan suatu konflik yaitu pertama strategi kompetisi dan strategi kolaborasi. Dua strategi ini berbeda satu dengan lainnya, dan tentu saja mengahasilkan dampak yang berbeda pula. Strategi kompetisi seperti manipulasi, coercon (paksaan) dan kekerasan hanya menghasilkan keuntungan jangka pendek, sedangkan secara jangka panjang akan mengorbankan hubungan, kerjasama dan kebersamaan. Sedangkan strategi kolaborasi melibatkan kerjasama antara kedua belah pihak untuk sama-sama mendiskusikan permasalahannya dan mencari pemecahan yang menguntungkan kedua belah pihak. Strategi kolaborasi di dalam memecahkan konflik menekankan tercapainya solusi menang-menang (win-win solution). Strategi kolaborasi di dalam memecahkan suatu konflik antara lain melalui cara negosiasi, mediasi, dan fasilitasi. Anak perlu dilatih untuk lebih banyak menggunakan strategi kolaborasi dalam hidupnya.

Mengembangkan sikap empati pada anak, empati adalah sejenis pemahaman perspektif yang mengacu pada respon emosi yang dianut bersama dan dialami anak ketika ia mempersepsikan reaksi emosi orang lain. Empati mempunyai dua komponen kognitif dan satu komponen afektif. Dua komponen kognitif itu adalah pertama, kemampuan anak mengidentifikasikan dan melabelkan perasaan orang lain. Kedua kemampuan anak mengasumsikan perspektif orang lain. Satu komponen afektif adalah kemampuan dalam keresponsifan emosi. Sikap empati anak dapat dilatih dengan menggunakan pertanyaan refleksi yang memfokuskan perhatian anak pada perasaan dan pikiran orang lain.

Mengembangkan sikap prososial pada anak, perilaku prososial adalah istilah yang digunakan oleh para ahli psikologi untuk menjelaskan sebuah tindakan moral yang harus dilakukan secara kultural seperti berbagi, membantu seseorang yang membutuhkan, bekerjasama dengan orang lain, dan mengungkapkan simpati. Perilaku ini menuntut kontrol diri anak untuk menahan diri dari egoismenya dan rela menolong atau berbagi dengan orang lain. Perkembangan perilaku prososial anak dipengaruhi terutama oleh lingkungan keluarga. Sehingga peran orang tua sangat besar dalam mendorong terbentuknya perilaku ini. Berikut beberapa cara yang bisa dilakukan untuk mengembangkan perilaku ini: ${ }^{1}$ Menjadi teladan bagi anak dalam berperilaku positif, Bertindak dengan adil dalam memberi perhatian dan kasih sayang pada semua anak., Mengajak anak mengikuti kegiatan-kegiatan amal sosial, Menjelaskan kepada anak keuntungan berperilaku prososial, Memuji anak ketika dia berhasil menunjukkan tindakan positif, Membimbing anak untuk mampu memilih teman-teman yang baik.

Mengajarkan berkomunikasi dengan santun pada anak, komunikasi merupakan sarana yang paling penting dalam kehidupan manusia. Komunikasi merupakan unsur yang mendorong kemajuan peradaban manusia, dan tanpa komunikasi, peradaban manusia tidak akan berkembang dengan pesat. Melalui kemampuan berkomunikasi menjadikan kehidupan manusia berbeda secara signifikan dengan makhluk ciptaan Tuhan lainnya. Komunikasi tidak 
Wijio, $S$.

Metode Pengembangan Social Question Pada Anak Dalam Perspektif Pembimbing

diragukan lagi karena harus dimiliki oleh setiap orang yang menginginkan kesuksesan dalam hidupnya.

Mengajarkan cara mendengarkan efektif pada anak, salah satu keterampilan komunikasi yang harus dimiliki oleh anak adalah keterampilan mendengarkan. Keterampilan mendengarkan ini akan menunjang proses komunikasi anak dengan orang lain. Sebab orang akan merasa dihargai dan diperhatikan ketika mereka merasa didengarkan. Sebuah hubungan komunikasi tidak akan berlangsung baik jika salah satu pihak mengacuhkan apa yang diungkapkannya. Mendengarkan membutuhkan perhatian dan sikap empati, sehingga orang merasa dimengerti dan dihargai.

Dari hasil penelitian yang ada, menunjukkan bahwa mendengar merupakan kegiatan yang paling banyak memakan waktu setiap harinya, dari seluruh aktivitas anak. Untuk itu keterampilan mendengarkan yang efektif sangat penting dimiliki oleh anak. Karena mendengar merupakan kegiatan komunikasi yang banyak menyita waktu di dalam interaksi sosial anak.

\section{KESIMPULAN DAN SARAN}

Berdasarkan hasil penelitian ini maka dapat disimpulkan bahwa pemahaman para pembimbing tentang kecerdasan sosial pada anak adalah bahwa kecerdasan sosial merupakan kemampuan yang ditunjukkan anak saat berinteraksi dengan orang lain atau lingkungan sosial. Metode yang digunakan pembimbing dalam mengarahkan anak untuk mengembangkan kecerdasan sosial dapat disimpulkan menjadi dua, yaitu: Bimbingan Individu, yang meliputi: mengembangkan kesadaran diri, mengajarkan pemecahan masalah efektif dan mengajarkan berkomunikasi dengan santun pada anak serta Bimbingan Kelompok, yang meliputi: mengajarkan pemahaman situasi sosial dan etika sosial, mengembangkan sikap empati, mengembangkan sikap prososial, dan mengajarkan mendengar efektif pada anak.

\section{DAFTAR RUJUKAN}

Abdurrahman An Nahlawi. 2004. Pendidikan Islam di Rumah Sekolah dan Masayrakat. Jakarta: Gema Insani

Ahmad Tafsir. 2004. IImu Pendidikan Dalam Perspektif Islam. Bandung: PT. Remaja Rosdakarya.

Alo Liliweri. 1991. Komunikasi Antar Pribadi. Bandung: PT. Citra Aditya Bakti.

Arifin. 1982. Pedoman Pelaksanaan Bimbingan dan Penyuluhan Agama. Jakarta: Golden Terayon.

Aunur Rahim Faqih. 2001. Bimbingan dan Konseling dalam Islam. Yogyakarta: UII Press.

Ayke S. Tedjasaputra. 2001. Bermain, Mainan dan Permainan. Jakarta: PT Grasindo.

Bandura, Albert. 1977. Social Learning Theory. Prentice-Hall, Inc., New Jersey

Damayanti, Ria, dkk. 2013. Studi Kasus Dampak Psikologis Bullying Pada Siswa Tunarungu Di Smk Negeri 30 Jakarta. Insight Jurnal Bimbingan dan Konseling Fakultas IImu Pendidikan Universitas Negeri Jakarta. Vol. 2 No. 2: 89.

Desmita. 2006. Psikologi perkembangan. Bandung: PT Remaja Rosdakarya. 
Wijio, $S$.

Dewa Ketut Sukardi. 2000. Pengantar Pelaksanaan Program Bimbingan dan Konseling di Sekolah. Jakarta: PT Reneka Cipta.

Edy Gustian. 2001. Mempersipakan Anak memasuki Usia Sekolah. Jakarta: Puspawara.

Elizabeth B. Hurlock. 1992. Perkembangan Anak Jilid I. Jakarta: Erlangga.

Hadi Suyono. 2007. Social Intelligence: Cerdas Meraih Sukses bersama Orang lain dan Lingkungan. Yogyakarrta: Ar-Ruzz media.

Hibana S. Rahman. 2003. Bimbingan dan Konseling Pola 17. Yogyakarta: UCY Press.

L.Tubbs, Stewart \& Moss, Sylvia. 2008. Human Communication : Prinsip-prinsip Dasar. Bandung: PT. Remaja Rosdakarya.

Lexy J. Meleong. 2007. Metode Penelitian Kualitatif. Bandung: PT Remaja Rosdakarya.

Mansur. 2009. Pendidikan Anak Usia Dini dalam Islam. Yogyakarta: Pustaka Pelajar.

Masri Singarimbun dan Sofyan Effendi. 1984. Metodologi Survei. Jakarta: LP3ES.

Safaria, T. 2005 . Interpersonal Intelligence. Yogyakarta: Amara Books. 